\title{
Protein, Methionine+Cystine and Lysine Levels for Japanese Quails During the Production Phase
}

- Author(s)
Garcia EA 1
Mendes $A^{1}$
Pizzolante $C^{2}$
Saldanha ESPB2
Moreira J33
Mori C ${ }^{3}$
Pavan AC 3
1 Professor, Departamento de Produção e
Exploração Animal
2 Researcher UPD Brotas/APTA /SAA, Brotas,
SP, Brazil
3 Graduate Student, Animal Science,
Faculdade de Medicina Veterinária e
Zootecnia, Unesp-Botucatu, SP, Brazil.

\section{Mail Address}

Edivaldo Antonio Garcia

Faculdade de Medicina Veterinária e Zootecnia, UNESP

CP 560

Distrito de Rubião Junior

18.690-1000. Botucatu, SP, Brazil

E-mail: egarcia@fca.unesp.br

\section{Keywords}

egg production, egg quality, Lysine, Methionine+Cystine, protein, quails.

\section{ABSTRACT}

An experiment was conducted at Faculdade de Medicina Veterinária e Zootecnia/Unesp - Botucatu for 168 days to evaluate the effects of protein, Met + Cys and lysine diet levels on egg production and egg quality of laying Japanese quails. Quails with 42 days of age were reared in a completely randomized design. There were 1,944 quails distributed in four replicates of 27 birds per pen, according to a factorial $3 \times 3 \times 2$ with three crude protein levels (16, 18 and 20\% CP), three Met + Cys levels $(0.700 ; 0.875$ and $1.050 \%)$ and two lysine levels (1.100 and $1.375 \%$ ). Birds fed diets with 18 and $20 \%$ CP had higher feed intake and egg production than those fed diets with $16 \%$ CP. There was significant interaction $(p<0.05)$ between protein and Met + Cys levels on egg weight. There was no effects ( $p>0.05)$ of the protein level on feed conversion per dozen eggs; however, improved feed conversion per egg mass was seen for birds fed diets with $20 \%$ CP compared to those fed diets with $16 \%$ and $18 \%$ CP. Protein and lipid percentage in the yolk increased when dietary protein level increased from 16 to $18 \%$. Increasing Met + Cys from $0.700 \%$ to $0.875 \%$ reduced yolk protein percentage. Higher lipid percentage in the yolk was seen in eggs from quails fed diets with $1.050 \%$ Met + Cys, whereas $1.375 \%$ lysine in the diet of resulted in decreased egg production and egg mass, besides poorer feed conversion per dozen eggs and per egg mass.

\section{INTRODUCTION}

Diet formulation for Japanese quails is usually based on nutrient requirement tables from other countries, which are not ideal for the tropical climatic conditions of Brazil. No new reports on the nutrient requirements for quails have been described since 1984 (NRC, 1994), evidencing the need of new information.

On the other hand, the increasing prices of corn and soybean meal and the greater commercial availability of the two most important limiting amino acids for birds (methionine and lysine) have drawn interest to diet formulation based on reduced protein levels with adequate amino acid supplementation.

Protein requirements have been reported to change according to age, so that quails aged 4,8 and 12 months required for maximal performance $14.6,16.5$ and $18 \%$ of protein in the diet, respectively (Schwartz \& Allen, 1981). Such results evidence the decrease in the ability of protein utilization in older birds; however, levels of $20 \% \mathrm{CP}$ and 3,000 kcal ME/kg are suggested by NRC (1984). Besides, levels recommended for Japanese quails during the laying period, no matter the age, were $20 \% \mathrm{CP}$ and $2,800 \mathrm{kcal} \mathrm{ME} / \mathrm{kg}$ (AEC, 1987) and $20 \% \mathrm{CP}$ and 2,900 kcal ME/kg (NRC, 1994).

Murakami (1991) evaluated nutrient requirements for laying quails 
Garcia EA, Mendes AA, Pizzolante CC, Saldanha ESPB, Moreira J, Mori C, Pavan AC

after 35 days of age and reported as adequate levels $2,700 \mathrm{kcal} \mathrm{ME} / \mathrm{kg}$ and $18 \% \mathrm{CP}$ in the diet during the laying period. Improved egg weight and feed conversion per egg mass were seen when the protein level of the diet was increased, whereas feed intake, laying rate, feed conversion per dozen eggs, shell percentage and shell thickness were not significantly affected.

The effects of two energy levels $(2,850$ and 2,950 $\mathrm{kcal} / \mathrm{ME} / \mathrm{kg}$ ) and five protein levels $(16 ; 18 ; 20 ; 22$ and $24 \%$ ) in the diet were evaluated for quails during the production phase (Pinto, 1998). Protein levels had a linear effect on the fourth period and a quadratic effect on the laying rate in two from the four periods that were studied, and maximum egg production was seen with 21.5 and $22.5 \%$ CP. Egg weight, shell weight, and feed conversion per dozen eggs and per egg mass were improved with increasing protein in the diet. There was a quadratic effect of the protein level on the produced egg mass, and maximum production was observed with $23.1 \% \mathrm{CP}$ in the diet.

On the other hand, egg production, feed intake and feed conversion were not different among treatments containing three different crude protein levels $(19,20$ and $22 \%)$ and three metabolizable energy levels $(2,400$, 2,600 and $2,800 \mathrm{kcal} \mathrm{ME} / \mathrm{kg}$ ), although egg weight was greater with $2,600 \mathrm{kcal}$ and $20 \%$ CP (Vidal et al., 2000)

Protein and amino acid requirements vary considerably according to the growth rate and egg production. Shim \& Cheng (1989) reported better egg production with $0.62 \%$ Met+Cys compared to 0.52 ; $0.57 ; 0.67$ and $0.72 \%$ Met+Cys. Similarly, during production, quails after 5 weeks of age require $0.375 \%$ of Met and $0.30 \%$ available Cys in a diet with $20 \%$ CP (Cheng \& Shim, 1989). Intake levels of $79.5 \mathrm{mg}$ available Met were required for maximum egg production.

Bello (1997) evaluated methionine levels in diets for quails in the early laying period. Diet levels were 19.2\% CP, $0.480 \%$ Met and $0.692 \%$ Met+Cys, and four other diets contained $16 \% \mathrm{CP}$, Met levels varying from 0.283 to $0.428 \%$, and Met + Cys levels from 0.549 to $0.692 \%$. Performance was better when Met + Cys levels in the diet were increased. Although egg characteristics were not affected, shell thickness was poorer with higher methionine levels.

Met + Cys levels were also evaluated by Scheideler \& Elliot (1998). Diets were formulated to provide 520, $590,660,730$ or $800 \mathrm{mg} / \mathrm{bird} /$ day and it was observed that birds fed with $520 \mathrm{mg} /$ day had decreased egg production and lower egg weight compared to the other groups. Feed efficiency, egg mass/bird/day, and the amount of solids in the yolk were improved with
Protein, Methionine+Cystine and Lysine Levels for Japanese Quails During the Production Phase

higher levels of sulfur amino acids. The percentages of albumen, yolk and dried shell were not significantly affected.

It has been reported that feed conversion and egg production were improved with $0.97 \%$ of lysine in the diet (Shim \& Lee, 1984). Similarly, Shim \& Lee (1985) evaluated the effects of lysine levels increasing from 0.9 to $1.3 \%$ on the fertility and hatchability and reported higher production and improvements in egg size, fertility and hatchability with $1.0 \%$ of lysine in the diet.

Japanese quails aged 60 days were fed with diets supplemented with synthetic amino acids that provided $16 \%$ CP and $0.16 \%$ sulfur amino acids, and diets containing $1.0 \%$ Lys, $0.43 \%$ Met and $0.18 \%$ Cys resulted in best egg production, egg weight and feed efficiency (Shim \& Lee, 1993). In Brazil, Oliveira (1998) reported similar estimated requirements for maximal egg production and egg weight $(1.07 \%$ and $1.08 \%$ lysine, respectively), and it was considered that the control diet with 19\% CP and 1.0\% Lys fulfilled the nutritional requirements for this amino acid.

Considering the contradictory results that have been reported and the few data available in Brazil about the protein and amino acid level requirements in Japanese quails, this study was carried out to evaluate the effects of protein, Met+Cys and lysine levels on the performance and egg quality of laying quails in the production period.

\section{MATERIAL AND METHODS}

The experiment was carried out at the Fazendas de Ensino, Pesquisa e Produção from Faculdade de Medicina Veterinária e Zootecnia (FMVZ), Universidade Estadual Paulista (UNESP), in Botucatu, SP, Brazil.

Two thousand and two hundred quails were reared from one to 35 days of age under similar management and feeding conditions. At 35 days of age, 1,944 birds were transferred to a production poultry house and housed in conventional quail cages throughout the experimental period (168 days).

Treatments were comprised of three protein levels $(16,18$ and $20 \%)$, thee Met+Cys levels $(0.700 ; 0.875$ and $1.050 \%)$ and two lysine levels (1.100 and $1.375 \%$ ) in the diet.

Ingredients used to produce the diet were analyzed in Laboratório de Análises Bromatológicas from FMVZ. Protein, calcium and phosphorus levels were determined, and metabolizable energy and amino acid levels were estimated according to Andriguetto et al. (1998). Chemical compositions and estimated 
Garcia EA, Mendes AA, Pizzolante CC, Saldanha ESPB, Moreira J, Mori C, Pavan AC
Protein, Methionine+Cystine and Lysine Levels for Japanese Quails During the Production Phase percentages of the experimental diets are shown in Table 1.

Egg production, feed intake, mean egg weight, egg mass, feed conversion per egg dozen and per egg mass, eggshell percentage, yolk percentage and albumen percentage were evaluated. Dry matter (DM) and percentages of protein, ether extract and ashes were determined in the yolk and albumen (AOAC, 1990).

Performance was analyzed according to a completely randomized design in a factorial arrangement $3 \times 3 \times 2$ (three protein levels, three methionine + cystine levels, two lysine levels) with 4 repetitions and 27 birds per parcel. Egg quality was assessed in five eggs collected per repetition during three days at the end of each 28-day period.

Results were submitted to analysis of variance and Tukey's test $(p<0.05)$ was used to compare significantly different means.

\section{RESULTS AND DISCUSSION}

Performance results of the Japanese quails submitted to the experimental treatments are shown in Table 2. Protein $(p<0.01)$ and lysine $(p<0.01)$ levels significantly affected laying rate. There were no significant effects of Met+Cys levels and there were no significant three-way interaction among the factors.

Birds fed $16 \%$ protein in the diet had decreased egg production compared to the other birds. Although birds fed $20 \%$ CP showed a tendency to higher egg production than birds fed $18 \%$ CP, no significant differences were seen. These findings are different from results reported previously by Vohra \& Roudybush (1971), Crivelli-Espinosa et al. (1980) and Sakurai (1981), who suggested that protein levels higher than $24 \%$ CP would maximize egg production. On the other hand, the results are similar to the value of $20 \%$ CP suggested by NRC (1994) and AEC (1987).

Egg production was not affected by Met+Cys levels in the diet, although production tended to be higher with increasing Met+Cys. Conversely, some previous studies have reported significantly increased egg production with higher Met+Cys levels (Resende, 1993; Murakami et al., 1994; Dabbert et al., 1996; Bello, 1997).

The increase in protein level from $16 \%$ to $18 \%$ resulted in higher feed intake, but feed intake was not significantly different between birds fed $18 \%$ or $20 \%$ CP. Increased feed intake was also reported with increasing protein levels in commercial layers (Yakout et al., 2000), and in studies that assessed protein levels for Japanese quails (Sakurai, 1981; Arscott \& PiersonGoeger, 1981). On the other hand, Cherici (1987) and Murakami (1991) reported no significant effects of protein diet levels on intake. These discordant results among studies may have resulted from the different levels of other nutrients in the diets, such as energy or calcium levels.

Feed intake was not affected by the increase in lysine and Met+Cys levels. Resende (1993) and Murakami et al. (1994) concluded that Met levels and sulfur amino acid levels in the diet had no effect on

\begin{tabular}{|c|c|c|c|c|c|c|c|c|c|c|c|c|c|c|c|c|c|}
\hline \multirow[t]{2}{*}{ Ingredients } & \multicolumn{17}{|c|}{ Treatments } \\
\hline & 1 & 2 & 3 & 4 & 5 & 6 & 7 & 8 & 9 & 10 & 11 & 12 & 13 & 14 & 15 & 16 & 18 \\
\hline Ground corn & 59.501 & 59.496 & 59.485 & 59.367 & 59.241 & 59.123 & 56.915 & 56.966 & 56.785 & 56.778 & 56.599 & 56.538 & 54.325 & 54.207 & 53.969 & 54.13353 .954 & +53.947 \\
\hline Soybean meal & 19.106 & 18.020 & 18.779 & 17.677 & 18.420 & 17.318 & 26.050 & 24.973 & 25.707 & 24.622 & 25.356 & 24.262 & 32.995 & 31.893 & 32.619 & 31.55832 .292 & 31.207 \\
\hline Wheat meal & 8.03 & 8.84 & 8.39 & 9.17 & 8.690 & 9.450 & 4.080 & 4.71 & 4.42 & 5.11 & 4.82 & 5.62 & 0.050 & 0.93 & 0.62 & $1.16 \quad 0.88$ & $\begin{array}{l}3.49 \\
3\end{array}$ \\
\hline Soybean oil & 1.965 & 1.954 & 1.915 & 1.934 & 1.926 & 1.945 & 1.946 & 1.919 & 1.926 & 1.915 & 1.922 & 1.925 & 1.926 & 1.945 & 1.967 & 1.910 & 1.906 \\
\hline Bicalcium phosphate & 1.383 & 1.381 & 1.383 & 1.378 & 1.377 & 1.372 & 1.410 & 1.410 & 1.408 & 1.406 & 1.403 & 1.400 & 1.438 & 1.433 & 1.429 & 1.432 & 1.428 \\
\hline Limestone & 8.665 & 8.672 & 8.667 & 8.675 & 8.672 & 8.681 & 8.613 & 8.618 & 8.616 & 8.623 & 8.620 & 8.628 & 8.650 & 8.568 & 8.567 & 8.571 & 8.575 \\
\hline Salt $(\mathrm{NaCl})$ & 0.350 & 0.350 & 0.350 & 0.350 & 0.350 & 0.350 & 0.350 & 0.350 & 0.350 & 0.350 & 0.350 & 0.350 & 0.350 & 0.350 & 0.350 & 0.350 & 0.350 \\
\hline DL-Methionine & 0.167 & 0.179 & 0.348 & 0.360 & 0.529 & 0.540 & 0.100 & 0.112 & 0.281 & 0.293 & 0.462 & 0.673 & 0.033 & 0.045 & 0.214 & 0.226 & 0.406 \\
\hline L-Lysine & 0.493 & 0.878 & 0.503 & 0.889 & 0.515 & 0.901 & 0.276 & 0.662 & 0.287 & 0.673 & 0.298 & 0.684 & 0.060 & 0.446 & 0.072 & 0.457 & 0.468 \\
\hline Choline Chloride & 0.060 & 0.060 & 0.060 & 0.060 & 0.060 & 0.060 & 0.030 & 0.030 & 0.030 & 0.030 & 0.030 & 0.030 & 0.003 & 0.003 & 0.003 & 0.003 & 0.003 \\
\hline Mineral supplement* & 0.100 & 0.100 & 0.100 & 0.100 & 0.100 & 0.100 & 0.100 & 0.100 & 0.100 & 0.100 & 0.100 & 0.100 & 0.100 & 0.100 & 0.100 & 0.100 & 0.100 \\
\hline Vitamin supplement** & * 0.200 & 0.200 & 0.200 & 0.200 & 0.200 & 0.200 & 0.200 & 0.200 & 0.200 & 0.200 & 0.200 & 0.200 & 0.200 & 0.200 & 0.200 & 0.200 & 0.200 \\
\hline Antioxidant (BHT) & 0.010 & 0.010 & 0.010 & 0.010 & 0.010 & 0.010 & 0.010 & 0.010 & 0.010 & 0.010 & 0.010 & 0.010 & 0.010 & 0.010 & 0.010 & 0.010 & 0.010 \\
\hline Total & 100 & 100 & 100 & 100 & 100 & 100 & 100 & 100 & 100 & 100 & 100 & 100 & 100 & 100 & 100 & 100 & 100 \\
\hline \multicolumn{18}{|c|}{ Calculated composition } \\
\hline ME (kcal/kg) & 2800 & 2800 & 2800 & 2800 & 2800 & 2800 & 2800 & 2800 & 2800 & 2800 & 2800 & 2800 & 2800 & 2800 & 2800 & 28002800 & 2800 \\
\hline CP $(\%)$ & 6.00000 & 16.000 & 16.000 & 16.000 & 16.000 & 16.000 & 18.000 & 18.000 & 18.000 & 18.000 & 18.000 & 18.000 & 20.000 & 20.000 & 20.000 & 20.00020 .000 & 20.000 \\
\hline Calcium (\%) & 3.500 & 3.500 & 3.500 & 3.500 & 3.500 & 3.500 & 3.500 & 3.500 & 3.500 & 3.500 & 3.500 & 3.500 & 3.500 & 3.500 & 3.500 & $3.500 \quad 3.500$ & 3.500 \\
\hline Total phosphorus (\%) & 0.600 & 0.600 & 0.600 & 0.600 & 0.600 & 0.600 & 0.600 & 0.600 & 0.600 & 0.600 & 0.600 & 0.600 & 0.600 & 0.600 & 0.600 & 0.600 & 0.600 \\
\hline Met+Cys (\%) & 0.700 & 0.700 & 0.875 & 0.875 & 1.050 & 1.050 & 0.700 & 0.700 & 0.875 & 0.875 & 1.050 & 1.050 & 0.700 & 0.700 & 0.875 & 0.875 & 1.050 \\
\hline Lys (\%) & 1.100 & 1.375 & 1.100 & 1.375 & 1.100 & 1.375 & 1.100 & 1.375 & 1.100 & 1.375 & 1.100 & 1.375 & 1.100 & 1.375 & 1.100 & 1.375 & 1.375 \\
\hline
\end{tabular}

* Levels per kg of diet: Manganese, 80.0 mg; Iron, 50.0 mg; Copper, 10.0 mg; Zinc, 50.0 mg; Cobalt, 1.0 mg; lodine, 1.0 mg; Selenium, 0.075 mg. * Levels per of diet: Vit. A, 120,000lU; Vit D3, 3,600 IU; Vit B1, 2.5 mg; Vit B2, 8 mg; Vit B6, 5 mg; Pantothenic acid, 12 mg; Biotin, 0.2 mg; Vit K3, 3.0 mg; Folic acid, 1.5 mg; Nicotinic acid, $40 \mathrm{mg}$; Vit B12, $20 \mathrm{mcg}$. 
Garcia EA, Mendes AA, Pizzolante CC, Saldanha ESPB, Moreira J, Mori C, Pavan AC

\begin{tabular}{|c|c|c|c|c|c|c|}
\hline $\begin{array}{l}\text { Nutrient } \\
\text { Levels }\end{array}$ & $\begin{array}{c}\text { Egg Production } \\
(\%)\end{array}$ & $\begin{array}{l}\text { Feed intake } \\
\text { (g) }\end{array}$ & $\begin{array}{l}\text { Egg weight } 1 \\
\text { kg/dozen(g) }\end{array}$ & $\begin{array}{l}\text { Egg Mass } \\
\text { (g) }\end{array}$ & $\begin{array}{l}\text { Feed conversion } \\
\text { kg/dozen }\end{array}$ & $\begin{array}{c}\text { Feed conversion } \\
\mathrm{kg} / \mathrm{kg}\end{array}$ \\
\hline \multicolumn{7}{|c|}{ Protein (\%) } \\
\hline 16 & $73.09 \mathrm{~A}$ & $24.45^{\mathrm{A}}$ & 11.32 & $8.29^{A}$ & 0.41 & $3.04^{\mathrm{B}}$ \\
\hline 18 & $74.94^{B}$ & $25.08^{B}$ & 11.52 & $8.65^{B}$ & 0.41 & $2.98 \mathrm{AB}$ \\
\hline 20 & $76.46^{B}$ & $25.33^{\mathrm{B}}$ & 11.69 & $8.95^{c}$ & 0.41 & $2.91^{\mathrm{A}}$ \\
\hline \multicolumn{7}{|c|}{ Met + Cys (\%) } \\
\hline 0.700 & 74.53 & 24.98 & 11.44 & 8.55 & 0.41 & 3.01 \\
\hline 0.875 & 74.61 & 24.91 & 11.59 & 8.67 & 0.41 & 2.97 \\
\hline 1.050 & 75.54 & 24.96 & 11.49 & 8.67 & 0.41 & 2.97 \\
\hline \multicolumn{7}{|c|}{ Lysine (\%) } \\
\hline 1.100 & $75.92^{\text {в }}$ & 25.00 & 11.48 & $8.73^{B}$ & $0.40^{\mathrm{A}}$ & $2.94^{\mathrm{A}}$ \\
\hline 1.375 & $73.74^{\mathrm{A}}$ & 24.90 & 11.54 & $8.52^{\mathrm{A}}$ & $0.42^{B}$ & $3.02^{B}$ \\
\hline
\end{tabular}

Means followed by different letters in the column are different by Tukey's test $(p<0.05) .1$ - Significant interaction Protein:Met+Cys.

the feed intake of quails in the laying period. Oliveira (1998) evaluated lysine levels varying from 0.65 to $1.45 \%$ in the diet of quails during production and reported no significant effects of lysine on feed intake.

There was a significant interaction between protein and Met+Cys levels in the diet (Table 3) on egg weight, which indicates that the main factors are dependent. Birds fed $18 \%$ CP and $0.875 \%$ Met+Cys had greater egg weight than birds fed $0.700 \%$ Met+Cys, whereas the birds fed $1.050 \%$ showed intermediate values. Within 16 and $20 \%$ CP, egg weight was not affected by Met+Cys levels. At $0.700 \%$ Met+Cys, eggs were heavier when birds were fed $20 \% \mathrm{CP}$. Within the Met+Cys level of $0.875 \%$, eggs were heavier at 18 and $20 \%$ CP. Finally, the increase in protein levels of diets containing $1.050 \%$ Met+Cys increased egg weight.

\begin{tabular}{lcccc}
\hline \multirow{2}{*}{$\begin{array}{c}\text { Table } \mathbf{3} \text { - Simple main effects of the interaction protein:Met+Cys } \\
\text { on the weight of eggs from laying quails. }\end{array}$} & Mean \\
\cline { 2 - 4 } Protein (\%) & \multicolumn{3}{c}{ Met + Cys (\%) } \\
& $\mathbf{1 6}$ & $\mathbf{1 8}$ & $\mathbf{2 0}$ & \\
0.700 & $11.23^{\mathrm{Aa}}$ & $11.38^{\mathrm{Aa}}$ & $11.71^{\mathrm{Ab}}$ & 11.44 \\
0.875 & $11.38^{\mathrm{Aa}}$ & $11.63^{\mathrm{Bb}}$ & $11.77^{\mathrm{Ab}}$ & 11.59 \\
1.050 & $11.35^{\mathrm{Aa}}$ & $11.54^{\mathrm{ABab}}$ & $11.58^{\mathrm{Ab}}$ & 11.49 \\
Mean & 11.32 & 11.52 & 11.69 & \\
\hline
\end{tabular}

Means followed by different capital letters in the column are different by Tukey's test $(p<0.05)$. Means followed by different small letters in the row are different by Tukey's test $(p<0.05)$.

Crivelli-Espinosa et al. (1980) and Pinto (1998) reported that Japanese quails fed $24 \%$ CP in the diet produced heavier eggs than birds fed lower protein levels. On the other hand, Costa et al. (1985), Cherici (1987) and Shrivastav et al. (1993) reported that egg weight increased when levels CP were increased up to $25 \%$ CP in the diet. The present findings corroborate results from Pires Júnior (1981) and Murakami (1991), who reported that egg weight may be improved with $20 \%$ CP levels. Although it has been previously reported that Met+Cys levels higher than $0.72 \%$ in the diet affect egg weight negatively (Shim \& Lee, 1988), in the present study there were no negative effects of increasing amino acid levels in egg weight at 16, 18 or $20 \%$ CP in the diet.

Higher protein levels in the diet improved egg mass. Nevertheless, an opposite behavior was seen with the increase in diet lysine levels. The effects of protein levels on egg mass may reflect the greater laying rate and egg weight that were also seen with increased protein levels, since egg mass is directly related to these parameters. Crivelli-Espinosa et al. (1980) reported maximum egg mass production with $19.4 \%$ CP in the diet.

It should be noted that protein levels higher than these may result in greater egg mass. Indeed, maximization of produced egg mass was seen with $22 \%$ CP (Kumar et al., 1978) and between 23 and $24 \%$ CP (Pinto, 1998).

There was no significant effects of Met+Cys levels on egg mass. On the other hand, Bello (1997) reported an increase in egg production and egg weight when sulfur amino acid levels up to 0.692 and $0.839 \%$ were used in the diet. It was reported that lysine levels affected egg mass significantly, and best results were seen with $1.1 \%$ Lys.

There was no significant effect of protein and Met+Cys, or of the interaction between these factors, on feed conversion ( $\mathrm{kg}$ feed: $\mathrm{kg}$ dozen eggs), although the worst results were seen with $1.375 \%$ Lys. Arscott \& Pierson-Goeger (1981), Schwartz \& Allen (1981) and Pinto (1998) reported significant protein effects on feed conversion. Feed conversion was improved by the increase in protein levels. Considering the sulfur amino acid levels, the present results partially corroborate the 
Garcia EA, Mendes AA, Pizzolante CC, Pavan AC Saldanha ESPB, Moreira J, Mori C,

results reported by Bello (1997). Feed conversion was affected by treatments containing Met+Cys levels from 0.549 to $0.839 \%$, so that feed conversion was poorer only at the higher lysine levels (1.375\%) (Bello, 1997). Therefore, recommended levels of lysine from $0.97 \%$ to $1.0 \%$ (Shim \& Lee, 1984) and from 1.0 to $1.1 \%$ (Shim \& Lee, 1985) seem to be adequate for laying quails.

Feed conversion ( $\mathrm{kg}$ diet : $\mathrm{kg}$ eggs) was improved with $20 \%$ protein and poorer results were seen with $16 \%$. Feed conversion with $18 \%$ CP was not statistically different from the other treatments.

Murakami (1991) observed improved feed conversion per egg mass with diet protein levels between 19 and 20\%, whereas Pinto (1998) reported improvement in feed conversion per egg mass with up to $22 \% \mathrm{CP}$ in the diet. Feed conversion was also improved as a function of Met+Cys (Resende, 1993; Bello, 1997). It was suggested that increased Met+Cys levels improved egg weight, and consequently, feed efficiency.

Although Shrivastav et al. (1990) suggested that $0.79 \%$ Lys in the diet is adequate for egg production, Shim \& Lee (1984), Shim \& Lee (1985) and NRC (1994) suggest levels of 0.97 ; from 1.0 to 1.1 ; and $1.0 \%$, respectively. The present findings and previous findings reported in the literature suggest that lysine levels between 1.0 to $1.1 \%$ are adequate for the optimization of feed conversion.

The effects of treatments on egg quality are shown in Table 4. There were no significant treatment effects on eggshell percentage. Murakami (1991) and Pinto (1998) also found that protein levels had no effect on this parameter. On the other hand, Bello (1997) reported increased egg weight and decreased eggshell percentage with increasing Met+Cys levels in the diet. In commercial laying hens, Novak \& Scheideler (1998)
Protein, Methionine+Cystine and Lysine Levels for Japanese Quails During the Production Phase

and Yakout et al. (2000) suggested that eggshell percentage may be reduced by higher lysine levels and by lower Met+Cys levels.

Improved yolk percentage was obtained with Met+Cys levels of $0.875 \%$ and $1.050 \%$, whereas protein levels had no effect on yolk percentage. Akbar et al. (1983) reported that higher protein levels in the diet increased yolk percentage and reduced albumen percentage in eggs from commercial laying hens. Nevertheless, Scheideler \& Elliot (1998) did not report influence of Met+Cys levels on the yolk percentage in laying hens, when daily intake was between 520 and 800 mg/bird/day, whereas Novak et al. (1999) and Yakout et al. (1999) reported decreased yolk percentage with the increase in lysine intake in laying hens.

No significant effects of protein, Met+Cys and lysine levels were seen on the percentage of albumen, and a significant interaction $(p<0.05)$ between Met+Cys and lysine was seen. The simple main effects from the factors (Table 5) showed higher albumen percentages with $1.10 \%$ lysine and $1.050 \%$ Met+Cys.

Akbar et al. (1983) reported that an increase in protein levels resulted in increased yolk percentage and decreased albumen percentage. On the other hand, the percentage of albumen in eggs from commercial laying hens was not affected by Met+Cys levels between 0.52 and $0.8 \%$ (Scheideler \& Elliot, 1998) or by lysine levels from 800 to $900 \mathrm{mg} /$ day and Met+Cys levels of 490 and $730 \mathrm{mg} /$ day (Yakout et al., 1999). Furthermore, Scheideler et al. (1996) reported that albumen percentage was not significantly affected by lysine levels between 500 and 1,000 mg/bird/day.

The percentage of protein in the yolk was significantly affected by protein levels $(p<0.01)$ and Met+Cys levels $(p<0.05)$. Birds fed $18 \%$ or $20 \%$ CP had higher protein levels in the yolk compared to the

\begin{tabular}{|c|c|c|c|c|c|c|}
\hline $\begin{array}{l}\text { Nutrient } \\
\text { levels }\end{array}$ & $\begin{array}{c}\text { Eggshell } \\
\text { (\%) }\end{array}$ & $\begin{array}{l}\text { Yolk } \\
(\%)\end{array}$ & $\begin{array}{c}\text { Albumen } \\
(\%)^{1}\end{array}$ & $\begin{array}{c}\text { Yolk } \\
\text { protein (\%) }\end{array}$ & $\begin{array}{c}\text { Albumen } \\
\text { protein }(\%)^{2,3}\end{array}$ & $\begin{array}{l}\text { Yolk ether } \\
\text { extract (\%) }\end{array}$ \\
\hline \multicolumn{7}{|c|}{ Protein (\%) } \\
\hline 16 & 8.57 & 31.34 & 60.09 & $30.03^{A}$ & 79.43 & $61.72^{c}$ \\
\hline 18 & 8.62 & 31.11 & 60.16 & $30.60^{B}$ & 79.68 & $61.41^{\text {в }}$ \\
\hline 20 & 8.68 & 31.21 & 60.10 & $30.72^{\text {в }}$ & 79.70 & $58.99^{A}$ \\
\hline \multicolumn{7}{|c|}{ Met+Cys (\%) } \\
\hline 0.700 & 8.65 & $31.03^{\mathrm{A}}$ & 60.21 & $30.68^{B}$ & 79.58 & $59.80^{A}$ \\
\hline 0.875 & 8.61 & $31.54^{B}$ & 59.86 & $30.26^{A}$ & 79.52 & $60.65 \mathrm{AB}$ \\
\hline 1.050 & 8.62 & $31.09 \mathrm{AB}$ & 60.29 & $30.41 \mathrm{AB}$ & 79.71 & $60.67^{B}$ \\
\hline \multicolumn{7}{|c|}{ Lysine (\%) } \\
\hline 1.100 & 8.64 & 31.22 & 60.07 & 30.42 & 79.56 & 60.47 \\
\hline 1.375 & 8.61 & 31.22 & 60.17 & 30.48 & 79.65 & 60.27 \\
\hline
\end{tabular}

Means followed by different letters in the column are different by Tukey's test $(p<0.05)$. 1 - Significant interaction Methionine + Cystine:Lysine. 2 - Significant interaction Protein:Methionine + Cystine. 3 - Significant interaction Methionine + Cystine:Lysine. 
Garcia EA, Mendes AA, Pizzolante CC, Pavan AC Saldanha ESPB, Moreira J, Mori C,

birds fed $16 \%$ CP in the diet. Such results corroborate previous findings from Andersson (1979) and Akbar (1983), who reported that yolk protein contents increased with higher protein levels in the diet.

\begin{tabular}{ccccc}
\hline $\begin{array}{c}\text { Table } \mathbf{5} \text { - Simple main effects of the interaction Met+Cis: Lysine } \\
\text { on the albumen percentage of eggs from laying Japanese quails. } \\
\text { Lysine (\%) }\end{array}$ & \multicolumn{3}{c}{$\begin{array}{c}\text { Met+Cys (\%) } \\
\text { Mean }\end{array}$} \\
\cline { 2 - 4 } & $\mathbf{0 . 7 0 0}$ & $\mathbf{0 . 8 7 5}$ & $\mathbf{1 . 0 5 0}$ & \\
1.10 & $59.96^{\mathrm{Aab}}$ & $59.72^{\mathrm{Aa}}$ & $60.52^{\mathrm{Ab}}$ & 60.07 \\
1.375 & $60.47^{\mathrm{Aa}}$ & $59.99^{\mathrm{Aa}}$ & $60.06^{\mathrm{Aa}}$ & 60.17 \\
Mean & 60.22 & 59.86 & 60.29 & \\
\hline
\end{tabular}

Means followed by different capital letters in the column are different by Tukey's test $(p<0.05)$. Means followed by different small letters in the row are different by Tukey's test $(p<0.05)$.

Higher protein percentage in the yolk was seen with $0.700 \%$ Met+Cys compared to $0.875 \%$ Met+Cys. Nevertheless, eggs from birds fed the diet with $1.050 \%$ Met+Cys had yolk protein levels similar to the other two groups.

Shafer et al. (1996) reported positive effects of the increase in total sulfur amino acid levels on yolk protein. As for lysine levels, Prochaska et al. (1996) reported no significant effects of 638 to $1,165 \mathrm{mg} / \mathrm{bird} /$ day on the protein contents of the yolk in eggs from 23-weekold laying hens.

Significant interactions were seen between protein and Met+Cys levels $(p<0.01)$ and between protein and lysine levels $(p<0.05)$ on the albumen protein levels (Table 6).

\begin{tabular}{|c|c|c|c|c|c|}
\hline \multirow[t]{2}{*}{ Protein (\%) } & \multirow[b]{2}{*}{ Lys (\%) } & \multicolumn{3}{|c|}{ Met+Cys (\%) } & \multirow{2}{*}{ Mean } \\
\hline & & 16 & 18 & 20 & \\
\hline 0.700 & & $79.27^{\text {Aa }}$ & $80.39^{\mathrm{Bb}}$ & $79.08^{\mathrm{Aa}}$ & 79.58 \\
\hline 0.875 & & $79.20^{\mathrm{Aa}}$ & $79.56^{\mathrm{ABa}}$ & $79.78^{\mathrm{ABa}}$ & 79.52 \\
\hline 1.050 & & $79.82^{\text {Aab }}$ & $79.10^{\mathrm{Aa}}$ & $80.23^{\mathrm{Bb}}$ & 79.71 \\
\hline \multirow[t]{3}{*}{ Mean } & & 79.43 & 79.68 & 79.70 & \\
\hline & 1.100 & $79.36^{\mathrm{Aa}}$ & $79.42^{\mathrm{Aa}}$ & $79.90^{\mathrm{Aa}}$ & 79.56 \\
\hline & 1.375 & $79.50^{\mathrm{Aa}}$ & $79.95^{\mathrm{Aa}}$ & $79.49^{\mathrm{Aa}}$ & 79.65 \\
\hline Mean & & 79.43 & 79.69 & 79.70 & \\
\hline
\end{tabular}

Means followed by different capital letters in the column are different by Tukey's test $(p<0.05)$. Means followed by different small letters in the row are different by Tukey's test $(p<0.05)$.

The simple main effects of the interaction between protein and Met+Cys shows that, for birds fed $18 \%$ CP in the diet, those fed with $0.700 \%$ Met+Cys had higher albumen protein than those fed with $1.050 \%$ Met+Cys. Considering the birds fed the 20\% CP diet, higher protein in the albumen was present in eggs from
Protein, Methionine+Cystine and Lysine Levels for Japanese Quails During the Production Phase

birds fed $1.050 \%$ Met+Cys than from birds fed $0.700 \%$ Met+Cys. On the other hand, within the group of $0.700 \%$ Met+Cys, birds fed 18\% CP had higher albumen protein than birds fed the other diets. Finally, for the birds fed $1.050 \%$ Met+Cys, those fed $20 \%$ of protein had higher percentage of albumen protein than those fed $18 \%$, whereas birds fed $16 \%$ protein were not different from the other groups.

Significant effects of diet lysine levels on the protein percentage of albumen in eggs from laying hens have been reported by Vogt \& Krieg (1982) and Prochaska et al. (1996) in one of two studies that were conducted. Such effect was not observed in the present study.

Protein levels $(p<0.01)$ and Met+Cys levels $(p<0.05)$ had significant effects on the ether extract percentage in the yolk. The increase in the protein levels resulted in a proportional decrease in the yolk ether extract. Nevertheless, the increase in Met+Cys level from $0.70 \%$ to $1.050 \%$ increased yolk ether extract. Similarly, Gardner \& Young (1972) reported that the increase in protein levels from 12 to $18 \%$ CP decreased ether extract percentage in the yolk and increased yolk protein percentage in the eggs from laying hens in the early laying period.

\section{CONCLUSIONS}

Egg production, feed intake, egg mass, protein and ether extract in the yolk were increased by diets with $18 \%$ CP and daily intake of $4.48 \mathrm{~g} \mathrm{CP}$ when compared to diets containing $16 \% \mathrm{CP}$, although there were no effects on feed conversion per dozen eggs.

Production performance or egg quality were not improved by Met+Cys levels higher than $0.70 \%$ and Met+Cys daily intake higher than $174 \mathrm{mg} / \mathrm{bird} /$ day.

Diet lysine levels higher than $1.10 \%$ and lysine daily intake higher than $275 \mathrm{mg} / \mathrm{bird} /$ day were inadequate since there was decreased egg production, egg mass and feed conversion per egg mass.

\section{REFERENCES}

AEC. Recomendação para a nutrição animal. 5. ed. Antony Cedex; 1987. $86 p$

Akbar MK, Gavora JS, Friars GW, Gowe RS. Composition of eggs by commercial size categories: Effects of genetic group, age and diet. Poultry Science 1983; 62:925-33.

Andersson K. Some unconventional feeds tuffs to laying hens 1 . Effects on production and gross chemical composition of eggs. Swedish Journal of Agricultural 1979; 9:29-36. 
Garcia EA, Mendes AA, Pizzolante CC, Saldanha ESPB, Moreira J, Mori C, Pavan AC
Andriguetto JM, Perly L, Minardi I, Gemael A, Flemming JS, Souza GA, Bona Filho A. Nutrição animal: as bases e os fundamentos de nutrição animal, os alimentos. 6. ed. São Paulo(SP): Nobel, 1998.

AOAC. Official methods of analysis of the Association of Agricultural Chemists. Agricultural chemicals, contaminants and drugs. $15^{\text {th }}$ ed. Arlington, 1990.

Arscott GH, Pierson-Goeger M. Protein needs for laying Japanese quail as influenced by protein and amino acid supplementation. Nutrition Report International 1981; 24:1287.

Bello MTS. Níveis de energia metabolizável e de metionina em rações de codornas japonesas (Coturnix coturnix japonica) na fase inicial de postura [dissertação]. Lavras (MG): Escola Superior de Agricultura de Lavras; 1997.

Cheng EV, Shim KF. The effect. of dietary methionine level on the laying performance and egg quality in laying Japanese quail. Singapore Journal of Primary Industries 1989; 17(1):48-58.

Cherici IC. Estudo da variação sazonal da exigência protéica de poedeiras comerciais [dissertação]. Jaboticabal (SP): Universidade Estadual Paulista; 1987

Costa BD, Baião NC, Campos EJ. Efeito do peso corporal, época de postura e níveis protéicos das rações sobre o desempenho de poedeiras comerciais. In: $9^{\circ}$ Congresso Brasileiro de Avicultura; 1985; Brasília, Distrito Federal. Brasil. p.55.

Crivelli-Espinosa J. Enriquez Velásquez F, Avila Gonzales E. Estudio con diferentes niveles de proteína en dietas de tipo practico para codornices japonesas em reproducción (Coturnix coturnix japonica). Tecnica Pecuária México 1980; 38: 13-7.

Dabbert CB, Lochmiller RL, Waldroup PW, Teeter RG. Examination of the dietary methionine requeriments of breeding northern bobwhite, Colinus virginarus. Poultry Science 1996; 75(8):991-7.

Gardner FD, Young LL. The influence of dietary protein and energy levels on the protein and lipid content of the hen's egg. Poultry Science 1972; 49:1687-92.

Kumar VSKB, Panda B, Reddy VR, Sadagopan VP. Protein and energy requirements for laying Japanese quail (Coturnix coturnix japonica). In: Journal World's Poultry Congress; 1978; Rio de Janeiro, RJ. Brasil. p.1350-60.

Murakami AE. Níveis de proteína e energia em dietas de codornas japonesas (Coturnix coturnix japonica) nas fases de crescimento e postura [tese]. Jaboticabal(SP): Universidade Estadual Paulista; 1991.

Murakami AE, Furlan AC, Tateishi A, Kira KC, Ribeiro RP. Níveis de metionina para codornas japonesas (Coturnix coturnix japonica) em postura. In: 31 Reunião Anual da Sociedade Brasileira de Zootecnia; 1994; Maringá, PR, Brasil. p.64

NRC - National Research Council. Nutrient requirements of poultry. $8^{\text {nd }}$ ed. Washington, D.C: National Academy of Science; 1984.

NRC - National Research Council. Nutrient requirements of poultry. $9^{\text {nd }}$ ed. Washington, D.C: National Academy of Science; 1994.
Protein, Methionine+Cystine and Lysine Levels for Japanese Quails During the Production Phase

Novak CL, Scheideler SE. The combined effect of lysine and TSAA in two strains of laying hens. Poultry Science 1998; 77 suppl 1:102.

Novak CL, Yakout $\mathrm{H}$, Scheideler SE. The effect of dietary lysine level and TSAA: Lysine ratio on egg production parameters and egg yield. Poultry Science 1999; 78 suppl 1:87.

Oliveira AM. Valores energéticos de alguns alimentos e exigência nutricional de lisina para codornas japonesas (Coturnix coturnix japonica) em postura [dissertação]. Maringá (PR):Universidade Estadual de Maringá; 1998.

Pinto R. Níveis de proteína e energia para codornas japonesas (Coturnix coturnix japonica) em postura [tese]. Viçosa (MG): Universidade Federal de Viçosa; 1998.

Pires Júnior JF. Diferentes níveis de proteínas em rações para codornas em postura [dissertação]. Jaboticabal (SP): Universidade Estadual Paulista; 1981.

Prochaska JF, Carey S, Shafer DJ. The effect of L-lysine intake on egg component yield and composition in laying hens. Poultry Science 1996; 75(1):1268-78.

Resende JAA. Níveis de proteína e aminoácidos sulfurosos em rações de codornas japonesas (Coturnix coturnix japonica) [tese Livre Docência]. Rio de Janeiro(RJ): Universidade Federal Rural do Rio de Janeiro; 1993.

Sakurai $\mathrm{H}$. Influence of dietary levels of protein and energy on nitrogen and energy balance for egg production of Japanese quail. Japanese Poultry Science 1981; 18:185-90.

Scheideler SE, Novak C, Sell JL. Hisex write Leghorn lysine requirement for optimun body weight and egg production during early lay. Poultry Science 1996; 75 suppl 1:86.

Scheideler SE, Elliot MA. Total sulfur amino acid (TSAA) intake to maximize egg mass and feed efficiency in young layers. Poultry Science 1998; 77 suppl 1:130.

Schwartz RW, Allen NK. Effect of aging on the requirement of mature female Japanese quail for egg production. Poultry Science 1981; 60:342-8.

Shafer DJ, Carey JB, Prochaska JF. Effect of dietary methionine intake on egg component yield and compositiom. Poultry Science 1996; 75(9):1080-86.

Shim KF, Cheng EV. Methionine requirement and its effect on the feather loss of laying Japanese quail. Nutrition Reports International 1989; 40:1003-10.

Shim KF, Lee TK. Effect of dietary lysine on egg production of laying Japanese quail. Singapore Journal of Primary Industries 1984; $12(2): 88-7$

Shim KF, Lee TK. Effect of dietary lysine on fertility and hatchability of breeding Japanese quail. Singapore Journal of Primary Industries 1985; 13:32-7.

Shim KF, Lee TK. Effect of dietary cystine on egg production of 
Garcia EA, Mendes AA, Pizzolante CC, Saldanha ESPB, Moreira J, Mori C, Pavan AC

laying Japanese quail. Singapore Journal of Primary Industries 1988; 16:34-0.

Shim KF, Lee TK. Effect of dietary essential amino acids on egg production of laying Japanese quail. Singapore Journal of Primary Industries 1993; 21:72-5.

Shrivastav AK, Panda B, Sadagopan VR. All vegetable diet with and without lysine and methionine supplementation and reproductive performance of laying Coturnix quails. Indian Veterinary Journal 1990; 67:941-7.

Shrivastav AK, Raju MVLN, John TS. Effect of varied dietary protein on certain production traits in breeding Japanese quail. Indian Journal Poultry Science 1993; 28(1):20-5.

Vidal JM, Silva YL, Figueiredo ACS. Influência de diferentes níveis de proteína bruta e energia metabolizável da ração no desempenho de codornas (Coturnix coturnix japonica) na fase final de postura. In: $2^{\circ}$ Congresso de Produção e Consumo de Ovos; 2000; São Paulo, São Paulo. Brasil. p.196.

Vogt $H$, Krieg G. Effect of excess Lysine in the feed on performance of laying hens and aminoacid composition of the eggs. Food Science and Tecnology Abstracts 1982; 16(7):94.

Vohra P, Roudybush $\mathrm{T}$. The effect of various levels of dietary protein on growth and egg production of Coturnix coturnix japonica. Poultry Science 1971; 50:1081-1084.

Yakout HM, Novak CL, Scheideler SR, Elliot MA. Interaction effects of lysine and TSAA on egg production parameters and egg components in laying hens. Poultry Science 1999; 78 Suppl 1:88.

Yakout H, Novak C, Sheideler S. Dietary protein level and variable TSAA: Lysine ratios: Effects on laying hens performance. Poultry Science 2000; 9 Suppl 1:93. 